CUADERNOS DE ESTUDIOS GALLEGOS, LVIII N. ${ }^{\circ} 124$, enero-diciembre (2011), pp. 11-28

ISSN 0210-847 X

\title{
IMÁGENES Y APOCALIPTISMO EN EL OCCIDENTE MEDIEVAL
}

\author{
ISRAEL SANMARTíN \\ Universidad de Santiago de Compostela
}




\title{
IMÁGENES Y APOCALIPTISMO EN EL OCCIDENTE MEDIEVAL
}

\section{RESUMEN}

En el presente artículo se estudiará la importancia de las imágenes en el mundo medieval y en concreto en algunas representaciones vinculadas a episodios escatológicos vinculados al apocaliptismo. Estudiaremos de forma separada tanto la imagen en el mundo medieval como un breve desarrollo del apocaliptismo. El fin último del trabajo será buscar los espacios de encuentro entre las imágenes y el apocaliptismo, que nos llevarán a reflexionar sobre diferentes iconografías apocalípticas y concluir en la importancia de la "localización" de las llamadas imágenes-objeto en relación a su función de hacer presente lo ausente y ejercer de productoras de lo real.

PALABRAS ClAVE: apocaliptismo, presencia, imagen, imagen-objeto, escatología, biblia iletrados.

\section{IMAGES AND APOCALYPTICISM IN THE MEDIEVAL WEST}

\begin{abstract}
This article will explore the importance of imagery in the medieval world and particularly in some representations related to eschatological events related to apocalypticism. We'll work separately the images in the medieval world and a brief development of apocalypticism. The ultimate stage of the article will seek opportunities for dialogue between images and apocalypticism, which lead us to reflect on different iconography and apocalyptic. We ended withthe importance of "location" of the so-called object-images in relation to its function of making the absent and present practice of producing real.
\end{abstract}

KEY WORDS: apocalypticism, presence, image, image-object, eschatology, bible illiterate. 
Recibido/Received: 01/07/2011

Aceptado/Accepted: 27/07/2011

$\mathrm{E}$ L objetivo fundamental de este artículo es mostrar algunas ideas sobre las imágenes en el mundo medieval, y en especial sobre los programas iconográficos apocalípticos. Trataremos de poner énfasis en diferentes aspectos, buscando lo iconográfico, lo mental, lo acontecimental y lo intelectual en el análisis que nos proponemos.

La configuración teórica y práctica del apocaliptismo gira en torno a la preocupación por el tiempo, la construcción de un mundo perfecto, el fin del mundo y el Juicio final. En todas estas matrices tienen una gran importancia las imágenes, las cuales, después de una época un tanto iconoclasta y luego de haberse mantenido durante siglos dentro de una iconicidad restricta y desconfiada, la cristiandad occidental experimentó desde el siglo IX y XI una expansión creciente de las imágenes, hasta el punto que se convirtieron en uno de los elementos constitutivos del sistema eclesial. Las funciones que asumen las imágenes en la sociedad cristiana son múltiples: ornamentos indispensables de culto a la virgen y los santos; ecos sensibles de la presencia real y de la Encarnación; emblemas de la Iglesia y señal de identidad de Instituciones; anuncios de las verdades escatológicas; sustento de prácticas devocionales, etc.

La presencia de las imágenes orquestan de manera sensible la sacralizad de los lugares de culto, de tal modo que contribuyen al contacto que allí se establece entre los hombres y las potencias santas o divinas, motiva la unión entre la iglesia material y la iglesia triunfante, así como la fusión en las liturgias terrenal y celestial. La mediación de las imágenes casi no se disocia de la que asumen los clérigos, puesto que se encuentran en objetos y lugares dedicados a ritos que manifiestan el poder sagrado de los sacerdotes. El desarrollo de las imágenes refuerza la institución eclesial y se convierten lentamente en los ornamentos indispensables del poder de la iglesia y "coadyuvantes emblemáticas de la mediación sacerdotal"1.

\footnotetext{
${ }^{1}$ Baschet, J., La civilización feudal. Europa del año mil a la colonización de América, Siglo XXI, México, 2009, p. 565.
} 
Por todo esto, las imágenes se asocian con la función de los lugares sagrados que polarizan el espacio feudal, mientras que la evaluación de sus formas responde a la dinámica general de la articulación de lo carnal y lo espiritual que anima a la cristiandad.

En ese sentido, dividiremos el trabajo en tres grandes apartados. Por un lado, nos detendremos en toda una serie de cuestiones teóricas en relación a las imágenes, en un segundo momento nos dentendremos en el contexto histórico, teológico, social e historiográfico alrededor del apocaliptismo medieval, entendido en conexión con el milenarismo y el fin de los tiempos. Y por último recurriremos a algunos ejemplos, para finalizar con unas breves conclusiones.

\section{LAS IMÁGENES EN EL OCCIDENTE MEDIEVAL}

La comprensión del Occidente medieval se completa con un análisis de las experiencias visuales y la imagen. Utilizando el concepto de "imagen" intentamos escapar a la noción de arte forjada desde el Renacimiento y forjada en la estética del siglo XVIII. Estudiaremos, por tanto, las imágenes medievales como un elemento más para lograr una comprensión general del Occidente Medieval. Las imágenes son tanto estéticas ("arte") como de la comprensión del amueblamiento del espacio medieval. Su importancia descansa tanto en sus virtudes formales como en los efectos que se pueden producir en el espectador ${ }^{2}$.

En un principio había una resistencia hacia las imágenes. La prohibición de las imágenes materiales figura en las tablas de la Ley de Moisés y los propios cristianos de los primeros siglos tenían muchas reticencias hacia lo visible, que se equiparaba con el mundo de las apariencias y del engaño ${ }^{3}$. Entre 730 y 843 se alternan fases de iconoclasia e iconodulia. Para los iconodulos, las imágenes estimulaban el descenso de Cristo y los Santos para estar entre los fieles, aunque muchos emperadores de esa época pensaban que las imágenes eran la causa de la cólera de Dios contra su pueblo y recomendaban no aceptar más símbolos que la cruz. Después de 843 la ortodoxia iconodula se impone definitivamente sobre una base de la teología del icono, de tal forma que los propios iconos hacen visible lo invisible y ayudan al hombre a acercarse a Dios. Lentamente, después de las restricciones de la época de Carlomagno, el Occidente cristiano termina por asu-

\footnotetext{
2 Jérôme Baschet denomina esto "imágenes-objetos", que serían objetos adornados y siempre en situación que participan de la dinámica de los vínculos sociales y las relaciones entre los hombres y el mundo sobrenatural. Ver BASCHET, Jërôme, L'iconographie médiévale, Gallimard, Paris, 2008, pp. 26-44. y pp. 156-166.

${ }^{3}$ Según tradición platónica, el mundo cristiano conoce durante su historia periodos de denuncia de las imágenes, incluso de iconoclasia. Ver BASCHET, Jërôme, L'iconographie médiévale, pp. 26-33.
} 
mir las imágenes y reconocerles un papel cada vez más importante. Incluso se desarrollará, basándose en las posturas de Gregorio Magno ${ }^{4}$, todo un argumentario sostenido en la idea de que las imágenes serían una suerte de "biblia de los iletrados" $"$, según la cual los iletrados mediante las imágenes comprenderían la historia santa y serían un sustituto del texto sagrado devaluado por la condición subalterna de sus destinatarios. Esta idea es matizable por dos cuestiones: a) el contexto en el que se desarrolla la postura inicial de Gregorio Magno (conversión de paganas e iconoclasia de Srenus) y b) se subraya que las imágenes sirven para preservar la memoria. Ya en los siglos XII y XIII la teología occidental de la imagen valora más el papel espiritual de las imágenes con la noción de "transitus", proceso mediante el cual a través de la semejanza de las cosas visibles nos elevamos hasta la contemplación de las cosas invisibles. La profusión de imágenes llevaría a transportar al espíritu humano hacia las esferas celestes, concretado especialmente en la adoración a Cristo ${ }^{6}$.

Más allá de todo esto, el año 1000 marca una inversión en la tendencia de las imágenes puesto que se fomenta las imágenes tridimensionales. Se pasa de la representación en las iglesias de una cruz a una "Imago crucifixi", es decir, a la imagen tridimensional de Cristo en la Cruz. Al mismo tiempo aparecen las primeras estatuas-relicarios, y los diferentes "sueños", que revelan a los vivos las virtudes de la imagen, gracias a la intervención sobrenatural de la figura santa que ésta representa ${ }^{7}$. Después de este momento, los tipos de imágenes se diversifican notablemente. Reaparece la pintura en tablas, los primeros retablos, polípticos, etc. Paralelamente, se desarrolla una importante estatuaria monumental en capitales, tímpanos con figuras y escenas diversas (entre las cuales están manifestaciones de Juicios Finales), así como miniaturas. Esta insistencia en lo figurativo tiene como origen la profundización en la oposición interior/exterior. La puerta se equivaldría a Cristo con el objeto de dar acceso a la salvación.

Las imágenes apocalípticas, por tanto, no tendrían una función muy diferente del resto de las mismas. Particularmente, las diferentes representaciones apocalípticas y de juicios finales intentan buscar una legitimación del poder temporal. Los Juicios Finales sirven como escenario para la impartición de justicia, ya sea del

\footnotetext{
${ }^{4}$ En el año 600, Gregorio Magno en su carta al obispo iconoclasta Serenus de Marsella, reprueba la destrucción de imágenes y justifica su empleo, afirmando que cumplen una función de enseñanza útil.

${ }^{5}$ Desarrollado especialmente historiográficamente desde: MÂLE, Émile, L'art religieux du XII siècle en France, A. Colin, Paris, 1924 y MÂLE, Émile, L'art religieux du XII siècle en France. Études sur l'iconographie du Moyen Âge et sur ses sources d'inspiration, A. Colis, Paris, 1948.

${ }^{6}$ Véase BONNE, Jean-Claude, “A la recherche des images medievales”, Annales ESC, 1991/2, pp. 353-373.

${ }^{7}$ Véase SCHMITT, Jean-Claude, Le corps des images. Essais sur la culture visuelle au Moyen Âge, Gallimard, Paris, 2002.
} 
Obispo, del Papa o de las autoridades seculares. La justicia terrenal se presenta como reflejo de la justicia divina, evocando al mismo tiempo esta suprema referencia con la esperanza de aumentar su autoridad. En el mismo sentido, las imágenes, son, como hemos señalado, parte de una serie de prácticas sociales destinadas tanto a laicos como a eruditos (la comprensión completa de las imágenes medievales requiere una cultura que sólo los clérigos poseen), pero también tienen otras funciones, como su asociación de culto con los santos y diferentes prácticas devocionales, así como un importante vínculo con la salvación (se hacen las oraciones ante algunas de ellas). Aunque, su papel fundamental es el "amueblamiento" en el marco de la liturgia y los sacramentos. En definitiva: instruir, rememorar y emocionar son las tres funciones fundamentales de las imágenes del Occidente medieval ${ }^{8}$.

Las iglesias son los lugares más vinculados con las imágenes a partir del siglo XI. Allí, las imágenes concuerdan de manera global con el funcionamiento litúrgico del lugar de culto, aunque con sus jerarquías internas: distinción entre la parte izquierda y la parte derecha; gradación desde las zonas inferiores hasta las partes elevadas; oposición entre el Oeste (muerte y diable) y Este (Cristo, Jerusalén y resurrección) muy evidentes en el Juicio Final ${ }^{9}$. La iglesia es una totalidad sagrada separada del mundo que posee una estructura interna diversificada que reproduce los ejes del mundo y las divisiones fundamentales de la sociedad. Es un sentido espacial que ordena la visión del universo y la hace sensible en la experiencia social común. La imagen redobla en forma sensible la manifestación litúrgica de las potencias celestiales y el decorado participa en la transferencia de realidad que lleva a cabo la liturgia.

En otro sentido, existe una relación entre la imagen y la esfera de lo imaginario. La visión espiritual, que engloba el conjunto de actividades de la imaginación y las imágenes del sueño y las visiones, no es ni visión corporal ni visión intelectual, sino un espacio intermedio. El sueño, como la visión mediante la vigilia, puede ser el instrumento de una comunicación con las potencias celestiales, con lo que la imaginación se convierte en una vía aceptada para la experiencia devocional o mística con lo que las interacciones entre la imagen material y la imagen mental se multiplican. Esto nos lleva también a considerar de forma diferente las relaciones entre lo verdadero y lo falso. En el mundo medieval, el universo sensible se considera como una imagen, un signo, y donde lo verdadero es la voluntad divina y todo lo que en el mundo sensible se interpreta de forma correcta para acercarse a la misma verdad. Así, la verdadera realidad es el más allá ${ }^{10}$

\footnotetext{
${ }^{8}$ BASCHET, Jërôme, La civilización feudal. Europa del año mil a la colonización de América, p. 543.

9 Ver Jerôme Baschet et Jean-Claude Schmitt (eds.), L'image. Fonctions et usages des images dans l'occident medieval, Cahiers du Léopard d’Or, 5, Paris, 1996.

10 Ver AUERBACH, Erich, Figura, Belin, Paris, 1993.
} 
mientras que el mundo sensible es todo una "figura". En las concepciones medievales, la verdad está en la interpretación que alcanza el sentido divino a través de sus figuras, más que en la realidad inmediatamente perceptible. Las imágenes no son sólo apariencias sino que son "figuras" en un mundo que es una gran "figura" y permite elevarse hasta las verdades celestiales.

Técnicamente, las imágenes medievales se mueven entre diferentes debates. Por un lado el de la ornamentación y representación. El arte medieval otorga gran importancia a la ornamentación, con lo que podemos hablar de una "ornamentalización" de las representaciones (incluidas figuras humanas y animales). Lo ornamental es cuando las figuras exhiben la literalidad de los trazos o los colores sin una preocupación ilusionista. Lo ornamental enriquece la representación de lo sagrado ya que exalta la divinidad mediante formas que contrapesan o subliman. Ya en el siglo XII-XIII la ornamentación se desplaza a los márgenes de la imagen ${ }^{11}$.

En cuanto al debate superficie/espacio, está insertado en esa concepción teleológica del arte hacia la tridimensionalidad como única meta posible y única representación correcta del espacio, generada por muchos historiadores del arte (Heinrich Wölfflin). Sería más adecuado hablar de un debate entre plenitud y volumen. La imagen medieval es plana porque debe un respeto a su soporte $\mathrm{o}$ al fondo que en el que se ubica, ya sean miniaturas en los libros o figuras esculturales o arquitectónicas. Las imágenes medievales buscan dar cierto volumen a las figuras. También se advierte una superposición de distintos planos, como por ejemplo en los pliegues de las vestimentas.

Sobre la consideración esencia/singularidad. Inicialment,e en las representaciones se evita prestarle características singulares e individualizantes, pero a partir del siglo XIII los rostros y los cuerpos se diversifican para expresar las particularidades de la edad, el sexo, y la personalidad individual. De tal forma, nacería el concepto de retrato en sentido moderno. Hay, por tanto, una evolución de la esencia genérica a la singularidad individual.

\section{Algunas REFleXiones SOBRE El APOCALIPTISMO MEDIEVAL}

Diferentes autores han estudiado la configuración de los miedos, los paraísos y la sociedad deseada futura ${ }^{12}$. En todas estas preocupaciones juega un papel importante el milenarismo, es decir, la segunda venida de Cristo para instaurar un Reino Terreno de mil años o reino de los justos, al que le seguiría un juicio final y el propio fin de los tiempos. Esta idea tuvo en el medievo todo tipo de variantes:

\footnotetext{
${ }^{11}$ Para este debate véase BONNE, Jean Claude, "Les ornements de l'histoire “, Annales HSS, 1996, $\mathrm{n}^{\circ} 1$, pp. 37-70.

12 Un ejemplo es J. Delumeau, El Miedo en Occidente, Madrid, 1989.
} 
juicio final antes o después del milenio; llegada de salvación colectiva y reino de justicia y paz. Todo esto envuelto en sucesos catastróficos y tanto en ambientes espirituales como populares, que en muchos casos son causa de rebeliones. Todas estas cuestiones han provocado problemas de datación ${ }^{13}$ y diferentes tensiones en las interpretaciones pero tienen un origen común y es el escrito judío referido al Capítulo 7 del libro de Daniel. El cristianismo heredó del judaismo el apocaliptismo aunque las enseñanzas de Cristo. El soporte principal del milenarismo cristiano es el capítulo 20 del apocalípsis de San Juan relacionado con la profecía de Daniel y los 1000 años que durarán el reino mesiánico (quiliasmo), aunque también hay que tener en cuenta la Epístola de Bernabé. Complementando al milenarismo cristiano, nos encontramos con el apocaliptismo (ruptura, drama, conmoción), mesianismo (venida de reinos).

El año 1000 o el concepto del año 1000 es una de las claves de bóveda de toda esta cuestión. Entendamos el año 1000 no como una fecha sino como un concepto en el que podemos englobar los diferentes años mil medievales (año 500 , año 800, etc.). En ese caso podemos abordar conjuntamente los diferentes terrores relativos a ese concepto. La idea moderna del "año 1000" data del siglo XVIII y fundamentalmente del siglo XIX cuando se recogen todas las interpretaciones apocalípticas en base a esto, gracias en parte a la lectura literal de textos como los de Glaber ${ }^{14}$ y a autores como Michelet en Francia o Sismunde de Sismundi en Italia Ya en el siglo XX, autores como Duby ${ }^{15}$ negaron los temores relativos al año 1000, reconociendo la inquietud de la población ante la posibilidad de ciertas fechas, pero negando la posibilidad de los temores colectivos. En los últimos años, Richard Landes ha rechazado la historiografía del año 1000 relativa a la no consideración de los terrores. Landes ha propuesto el estudio de un milenarismo escondido. Los mismos escritos de Abbon de Fleury cerca del año mil podrían ser muestra de un milenarismo sumergido pero poderoso. La escasez de menciones en los textos se debe a la capacidad silenciadora, pero hay escritos que denotan preocupaciones de las minorías ${ }^{16}$ e incluso los Oráculos Sibilinos. También en el ámbito hispano se han señalado diferentes textos con un enfoque más apocalíptico que milenarista (San Isidoro, J. de Toledo o Beato de Liébana) ${ }^{17}$.

13 Como ha señalado Richard Landes en LANDES, Richard, Relics, Apocalypse, and the Deceits of HistoryAdémar de Chabannes (989-1034), Harvard University Press, Cambridge, 1995.

${ }_{14}$ GLABER, Raul, Historias del primer milenio, Consejo Superior de Investigaciones Científicas, Madrid, 2004.

15 DUBY, George, L'An mil, Julliard, París, 1967

16 B. McGinn, Visions fo the End, y C. Carozzi y H. Tavianni, La fins des Temps. Terreurs et prophéties au Moyen Âge, Paris, 1982.

17 Ver RUQUOI, Adeline, "El fin del milenarismo en la España de los siglos X y XI", en J. I. De la Iglesia Duarte, Milenarismos y milenaristas en la Europa Medieval, Instituto de Estudios Riojanos, Logroño, 1999, pp. 281-305. 
Como hemos dicho, entendamos los terrores del año 1000 como un concepto. Si nos vamos al año 800 podemos encontrar textos de Elipando (Toledo), Alcuino (Tours), el Beato de Liéabana ya mostraban una gran preocupación por "inquietudes" más que "temores" colectivos. Son escritos milenaristas en el sentido de que va a legar el fin del mundo pero no el juicio final.

El mito sobre el milenarismo tan discutido gira en torno a diferentes tópicos: a) las Crónicas de Guillermo Goder y Abbón de Fleury. Se recoge un testimonio donde en un sermón se alude al fin del mundo. No está asociado a histerias ni al año 1000; b) expresiones que aparecen en documentación medieval relativas al "Mundo in finem", que no reflejan un sentimiento colectivo y no muestran psicosis; c) expresión “año 1000” y el problema de las dataciones: último año del siglo IX, primero del XI; d) cronistas, como Raoul Glaber (siglo XI) que muestran que no es una cuestión generalizada puesto que diferentes historiadores han desbaratado las ideas de Glaber como Orsi, Roy, Duval, que muestran que sólo algunos iluminados hablaban entre 960-1000 del fin del mundo y sí hay en todo caso un "milenarismo retrospectivo"; e) en la Península ibérica se habla de esperanzas milenaristas hasta el siglo $\mathrm{X}$, cuando se abandona la espera y se continúa la historia escribiéndola y viviéndola; f) toda la cuestión de las dataciones en torno al 500, 800 y 1000, cuando va a llegar el fin del mundo se posterga.

En los últimos años autores como R. Landes o J. Fried han realizado una profunda revisión de estos supuestos, a la vez combatidos por Sylvain Gouguenheim en su libro sobre los falsos terrores del año 1000, donde defiende que el cristianismo es escatológico pero no milenarista; la angustia de la salvación individual superaba el miedo al juicio final. Y subrayaba que el milenarismo es más cosa de clérigos. Frente a esto, Lnades encuentra en los siglos X y XI muchos textos y propone una nueva lectura de los mismos, en el sentido de interpretar silencios, ausencias y las múltiples manifestaciones de la mentalidad apocalíptica. En buena medida, Landes demuestra que entre 980-1030 hay signos anunciadores del fin del mundo. La idea de "fin" impregnó la mentalidad del Norte de Francia, Alemania e Inglaterra.

Este milenarismo no se puede entender sin la importancia de la teología o del pensamiento medieval en la Edad Media. San Agustín es la versión doctrinal de todo este problema y el fin de todo milenarismo (Ebonitas, doctrinas de Crinto, San Justino, San Ireneo de Lyon, Montano, etc.). Su explicación se convierte en canónica para la Iglesia al explicar que el reino de Cristo no debe se esperado al final de los tiempos, es el actual sobre la Iglesia y que mil años es una cifra simbólica que explica el fin de los tiempos. Con San Agustín el milenarismo como doctrina desaparece de la ortodoxia cristiana por lo menos en teoría. Landes y Cohn afirman que el milenarismo estuvo presente en diferentes manifestaciones religio- 
sas populares pero que es reprimida constantemente. Para entender el fenómeno en su conjunto hay que tener en cuenta las referencias indirectas, alusiones veladas y tener en cuenta que son argumentaciones milenaristas aquellas calamidades naturales, fenómenos astronómicos, cambios climáticos así como los movimientos populares milenaristas y todo lo relativo a la edad del mundo (San Hipólito, Eusebio de Cesarea y San Jerónimo). Joaquín de Fiore tendrá otra significancia para todo esto al articular una doctrina trinitaria que fue condenada como herética al mostrar un programa de perfección de la humanidad hasta la espiritualización final. Se le atribuyen ideas con posteridad que proporcionaron un arsenal de inquietudes apocalípticas. Toda una serie de órdenes mendicantes se convertirán en monjes espirituales de la Tercera Edad, y diferentes movimientos sociales encontraron en Joaquín de Fiore. El joaquinismo se difunde en el franciscanismo y tuvo influencia en Pedro J. Olivi y otros movimientos espirituales y sociales: los fraticelli, grupos de flagelantes, hermanos apostólicos de Gerardo Segarelli, etc. Por tanto, no debemos de ver los conflictos sociales alejados de todo esto independientemente de las diferentes concepciones de los mismos, ya sean entendidos como resultados de un milenarismo de oprimidos frente a opresores (interpretación marxista), la del resultado de la tendencia irracional de las masas $(\mathrm{Cohn})^{18}$ o como resultado de factores intelectuales, espirituales, políticos y sociales.

Estos debates hay que complementarlos con el debate historiográfico que hay en torno a la mutación del año 1000, donde los argumentos demográficos, expansión territorial, nuevas técnicas, reformas eclesiásticas, etc. son elementos para explicar la mutación/graduación (Bournazel/Bonassie) de la llamada revolución feudal donde el señorío sustituye a la antigua esclavitud. Aquí hay todo un debate sobre si el cambio social fue revolucionario (Duby) o si fue más vinculado a otro tipo de movimientos más graduales donde las prácticas feudo-vasalláticas (Berthelemy) eran antiguas y se conformarían gradualmente.

\section{PRINCIPALES ICONOGRAFÍAS APOCALÍPTICAS}

El estudio de las imágenes del Apocalipsis nos hace ver la influencia del Este en el Oeste medieval. Esto explicaría los orígenes de esas imágenes escatológicas en las religiones griegas, en la mitología, en la gigantomaquia, en la demonología, en laangealogía, etc (las visiones celestes descritas por la biblia y por el Apocalipsis están dominadas por la presencia de Ángeles). De alguna forma, el Apocalipsis describe las tribulaciones que los hombres sufren para presentarse en el Juicio Final. El ángel, la espada, la mujer o el libro de la vida, constituyen parte

$18 \mathrm{COHN}$, Norman, En pos del milenio revolucionarios milenaristas y anarquistas místicos de la Edad Media, Barral Editores, Barcelona, 1972. 
de la iconografía característica de las representaciones apocalípticas. Todas, con permiso de la trompeta, que es uno de los signos anunciadores de la parusía. Las ideas apocalípticas no encontraron ningún obstáculo para penetrar en Francia o en España. Así tenemos la portada de la Iglesia de Saint Pierre de Moissac (siglo XII), donde los 24 ancianos portan las coronas de oro y portan las cítaras o el Tímpano de la Lande de Cubzac (Gironde) que representa a Cristo con la Espada (Siglo XI) y que sostiene en su mano 7 estrellas. En el siglo IX se encuentran los primeros manuscritos que podríamos denominar como Biblias. El promotor de esos libros fue Alcuino, a la postre reclutado por Carlomagno para su empresa cultural denominada "renacimiento carolingio". Sin embargo, no fue hasta el siglo XII con la figura de Joaquín de Fiore cuando se extrae el Apocalipsis de sus límites romanos. Fiore declaraba vivir en el sexto signo del Apocalipsis y los fieles ansiosos se tumbaban a ver las estrellas en el cielo... Sus profecías eran muy escuchadas en ese momento e incluso era consultado por grandes notables de la época. De todas formas, el Apocalipsis y el fin del mundo también fueron temas que se desarrollaron en el siglo $\mathrm{XV}^{19}$.

El simbolismo de las cifras y de los colores en las representaciones apocalípticas también es otra cuestión a reseñar. Así, el número “7” o el color blanco son especialmente significativos en ese sentido. También hay otras cuestiones como los "15" signos del fin del mundo o la leyenda dorada de la Sibila Dies Irae.

En el románico podemos encontrar diferentes manifestaciones apocalípticas. Por un lado el grupo español de los "Beatos". El desarrollo del Apocalipsis en Occidente coincide con el Imperio de Carlomagno, y no fue alterado por la llegada de los árabes a España ni por la crisis iconoclasta en Bizancio. Así tenemos el Beato de Liébana que vivió en el siglo VIII, el de Silos del siglo XI o el de la Catedral de Gerona, que representa el éxtasis de Juan simbolizado por un hijo que se escapa de una paloma Estos beatos tuvieron su continuación en el Beato de la Biblioteca Nacional de París de gran formato y gran aspecto monumental. Después de los Beatos, en el siglo XI se llega a una nueva fase, que es la del retorno al arte romano, escenificado en el Beato de Berlín y la Biblia de Rosas. La idea de Juicio Final como consecuencia inmediata del fin del mundo era una preocupación importante para la población de la época medieval ${ }^{20}$. Así, hay diferentes representaciones, como la de la Iglesia de Saint Pierre de Santi-Benoît-sur-Loire, así como el tímpano de la "Lande de Cubzac". ${ }^{21}$

\footnotetext{
19 VEZIN, Gilberte, L'Apocalypse et la fin des temps, Editions de la Revue Moderne, Paris, 1973, pp. 25-39.

20 "Les jugements derniers remuèrent plus profondément les âmes que nous ne pouvons nous le figurer. De telles scenes ne furent pas regardées sans anxiiété. Le fidèle, en passant sous le porche des églises, songeail que ces anges qui sonnaient de la trompette sur sa tête, il pouvait les entendre Derain", VEZIN, Gilberte, L'Apocalypse et la fin des temps, p. 84

21 VEZIN, Gilberte, L’Apocalypse et la fin des temps, pp. 25-39.
} 
Ya en el gótico, el anticristo es uno de las actores fundamentales de las iconografías., además del desarrollo de frescos y esculturas de gran influencia italiana, como se puede comprobar en el Palais des Papes à Avignon. También se fomentaron las tapicerías y las vidrieras.

Por tanto, las imágenes alcanzan una importancia cada vez mayor en el Occidente Medieval. Esto es un símbolo distintivo en relación a otras civilizaciones ${ }^{22}$. El experto J. C. Schmitt lo ha denominado la "revolución de las imágenes" aunque algunos especialistas desvinculan todo eso del concepto de Arte tal y como se concibe a partir del siglo XVIII en dos sentidos: a) las imágenes medievales no tendrían una finalidad estética autónoma; b) la noción de artista no se diferenciaría de la de artesano. Sus funciones serían tanto laicas como intelectuales, donde los santos, sus imágenes y lo asociado a lo milagroso/maravilloso/mágico ${ }^{23}$ serían un puente entre lo real y lo imaginario vinculado a verdades escatológicas. En otro sentido, las imágenes orquestan la sacralidad de los lugares de culto y refuerzan la institución eclesial. La imagen medieval no es el origen de la civilización de la imagen pero sí podemos decir que está en función de su localización y es un objeto imaginado e imaginario donde se combina lo corporal y lo espiritual, donde hay una diferenciación entre lo real y lo representado, lo real y lo ideal, y donde la presencia de la imagen (real o imaginada) tiene una gran efectividad para las creencias cristianas.

Las imágenes medievales están dentro de la historia. No reflejan la realidad pero forman parte de ella. Son parte de los actos sociales y de las interacciones entre el hombre y el más allá. Las imágenes están en la historia no porque son el producto de lo real (y lo ideal) sino porque son productores de lo real (y de lo ideal e imaginario), aunque las imágenes no son la biblia de los iletrados pese a su eficacia y capacidad operativa. En los siglos X-XI asistimos a una revolución iconográfica tridimensional a la vez que se ampliaron los temas y los capiteles, de figuras y de las escenas más variadas. Se amplían los espacios con figuras y en el siglo XI aparecen los primeros tímpanos esculpidos a la vez que se reordena territorialmente el establecimiento de villas y parroquias. Las imágenes tienen que ver con el imaginario con lo maravilloso y con el hombre/Dios. En los siglos XI-XII florecieron los temas apocalípticos en el arte. En el 1080 en Italia y en el Sur de Francia así como en el Norte de la Península Ibérica. Aparecieron representaciones del juicio final, de fuegos de Babilonia, aparición de Cristo en la Nube, etc.

De todas formas, las iconografías de las escenas principales del Apocalipsis son las siguientes:

22 BASCHET, Jérome, L’iconographie médiévale, Gallimard, Paris, 2008.

23 LE GOFF, Jaques,, Lo Maravilloso y lo cotidiano en el occidente medieval, Gedisa, Barcelona, 1999. 


\section{Juan escribano (Apocalipsis I 9)}

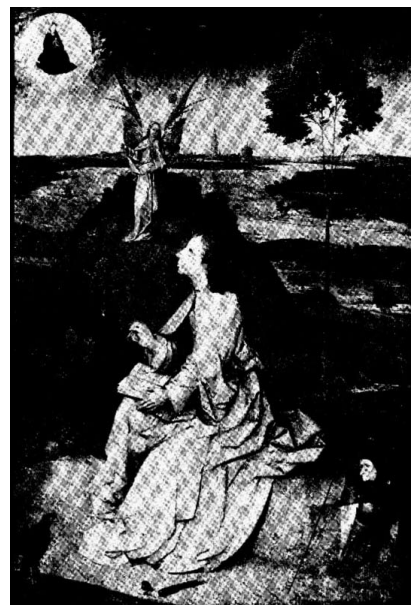

Fig. 1

Tableau du Musée de Berin de Jérôme Bosch. Siglo XV 24

Cristo y la espada (I 12-20)

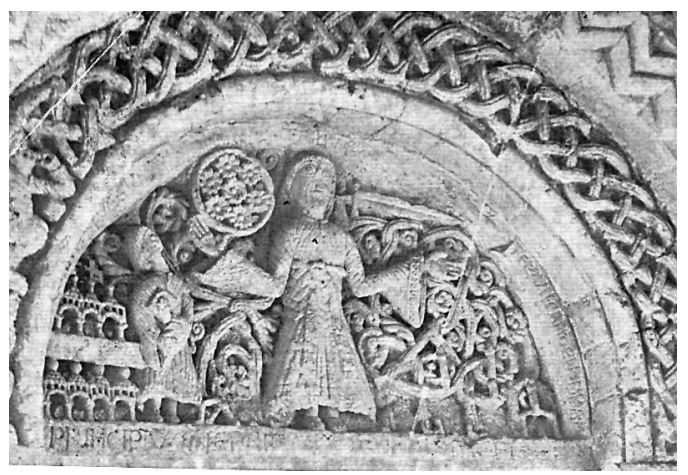

Fig. 2

Timpano de la Lande de Cubzac (Gironde). Siglo XI ${ }^{25}$

\footnotetext{
24 VEZIN, Gilberte, L'Apocalypse et la fin des temps, (figura 152). Las páginas de las ilustraciones no están numeradas.

25 VEZIN, Gilberte, L'Apocalypse et la fin des temps (figura 2).
} 
La adoración de los 24 ancianos (Apoc. IV y V)

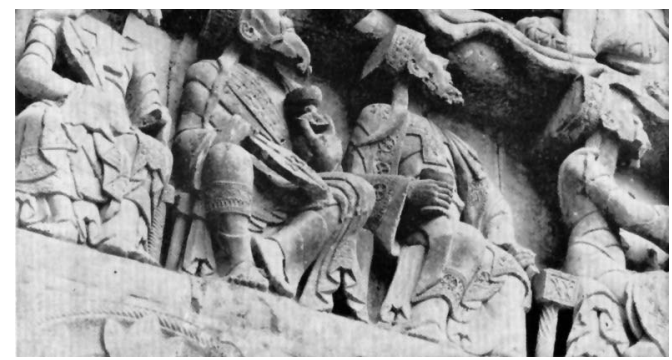

Fig. 3

Portada de la Iglesia de Saint Pierre de Moissac. Siglo XII ${ }^{26}$

Apertura de los 6 primeros sellos. Los 4 caballos (Apoc. VI y VII)

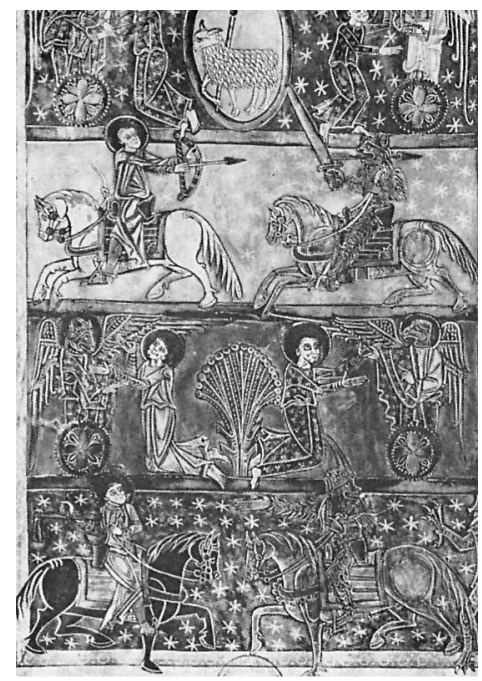

Fig. 4

Bato de París. Los cuatro caballeros ${ }^{27}$

26 VEZIN, Gilberte, L'Apocalypse et la fin des temps (figura 98).

27 VEZIN, Gilberte, L'Apocalypse et la fin des temps, (figura 104). 
Apertura del séptimo sello y distribución de las siete trompetas (Apoc. VIII y IX)

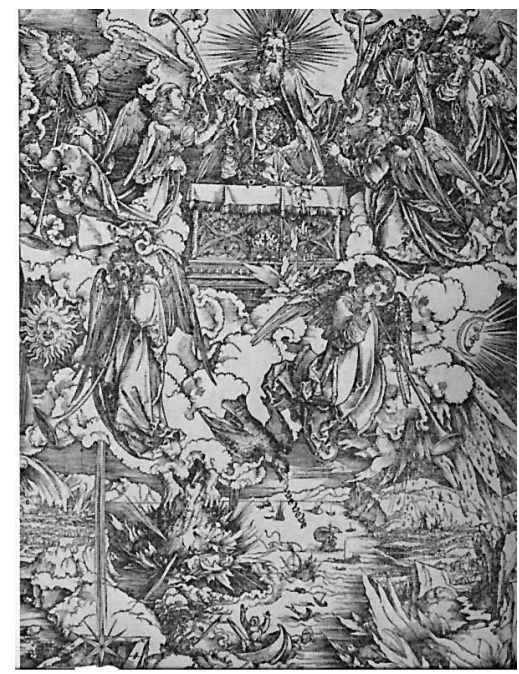

Fig. 5

Gravure de Dürer. Distribución en los ángeles de las siete trompetas ${ }^{28}$

El ángel anunciando el juicio final (Apoc. XIV 6-8)

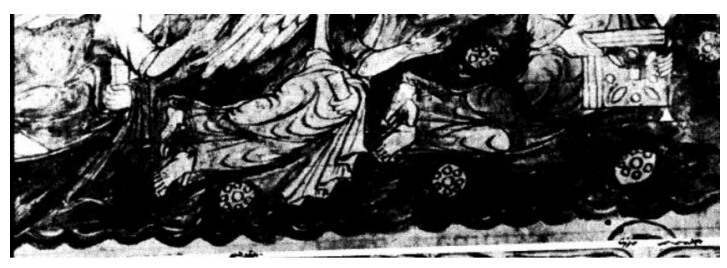

Fig. 6

Apocalipsis carolingio de Cambrai ${ }^{29}$

28 VEZIN, Gilberte, L'Apocalypse et la fin des temps, (figura 118).

29 VEZIN, Gilberte, L'Apocalypse et la fin des temps, (figura 21). 
Los dos testigos (Apoc. XI 1-4)

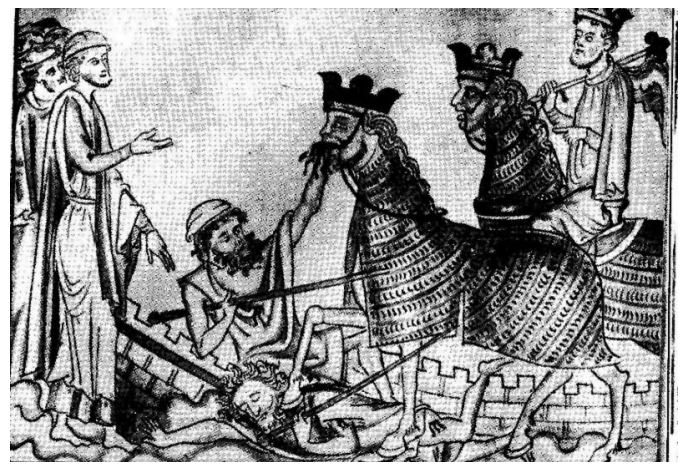

Fig. 7

Apocalipsis de Cambrai $^{30}$

La mujer coronada con 12 estrellas (Apoc. XII)

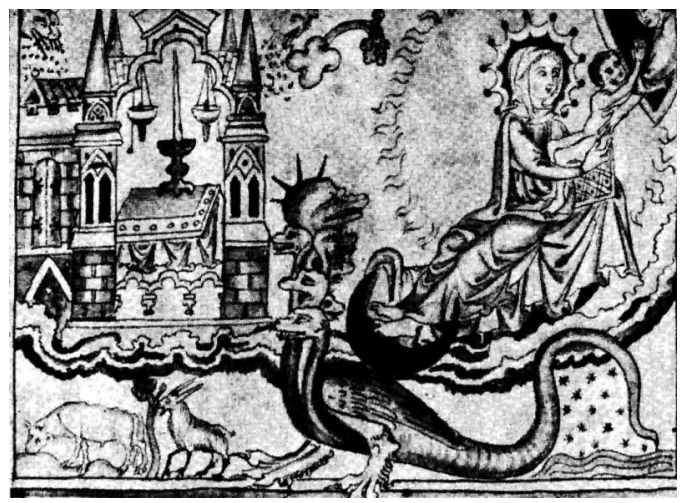

Fig. 8

Apocalipsis de Cambrai $^{31}$

30 VEZIN, Gilberte, L'Apocalypse et la fin des temps, (figura 75).

${ }^{31}$ VEZIN, Gilberte, L'Apocalypse et la fin des temps, (figura 129). 
El combate de San Miguel y el Dragon

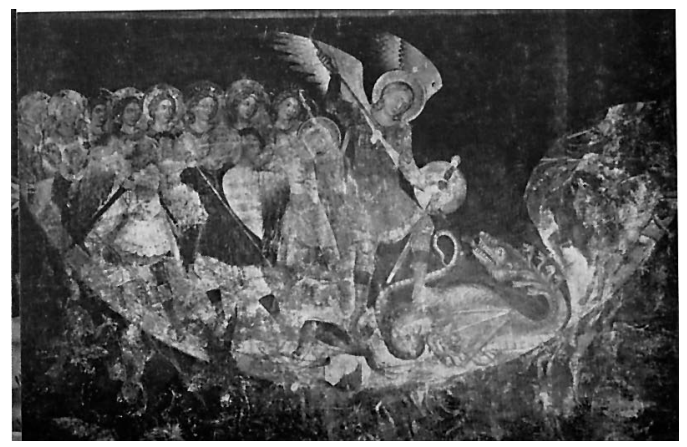

Fig. 9

Capilla Velluti de la iglesia de Santa Crece de Florence. Siglo XIII ${ }^{32}$

\section{CONCLUSIONES}

Como señala Jérôme Baschet la imagen-objeto medieval no tiene sentido más que por su carácter localizado. Y también es un objeto imaginario e imaginado que pone en relación la visión corporal y espiritual. En definitiva, la representación también es presencia e instrumento de una manifestación eficaz de las potencias celestiales. La presencia de la imagen-objeto sólo pesee veracidad en la medida en que uno se coloca en el campo de las creencias cristianas de tal forma que la imagen medieval participa de una relación con la ilusión que se vive realmente. El estatuto y las prácticas de las imágenes son indisociables de la organización general de la sociedad ${ }^{33}$.

Tal y como hemos visto la historia, el pensamiento y las diferentes manifestaciones apocalípticas están conectadas entre sí y es muy difícil discernir los planos. El mundo apocalíptico y milenarista está vinculado muy estrechamente con la salvación y con el concepto religioso medieval. La importancia de las imágenes en el debate sobre el milenarismo, apocaliptismo y fin del mundo ha quedado demostrado aquí. Con ellas, podemos explicar mejor el debate en torno a los miedos y los terrores del año mil, así como las preocupaciones tanto intelectuales como de "presencia" de las diferentes escenas. Por tanto, para la reconstrucción de los presentes medievales será necesario recurrir tanto a crónicas como documentación pero también a las imágenes que son válidas para ver la evolución y la recreación

\footnotetext{
32 VEZIN, Gilberte, L'Apocalypse et la fin des temps, (figura 66).

33 BASCHET, Jérôme., La civilización feudal. Europa del año mil a la colonización de América, p. 566.
} 
de las memorias. "Presencia", "realidad" y "localización" son tres conceptos que hemos manejado para llevar a cabo este pequeño trabajo en el que hemos puesto de relevancia la importancia del diálogo entre el arte medieval y la escritura medieval y entre los historiadores y los historiadores del arte, en un intento de interdisciplina que nos ha llevado a conclusiones muy relevantes para el objeto de estudio: si nos asomamos a las imágenes y sus representaciones no podemos negar la ausencia de terrores, de inquietudes y de preocupación por los fines (de la historia, del tiempo, etc.) en la Edad Media. 